\title{
THE REPRESENTATION OF WOMEN IN DYSTOPIA: A COMPARATIVE STUDY
}

\author{
Aisha Arshad ${ }^{1}$, Prof. Muhammad Safdar Bhatti ${ }^{2 *}$ \\ ${ }^{1}$ Instructor, SAQE, Bahawalpur-Pakistan, Saqe1994@gmail.com \\ ${ }^{2}$ Prof, TEFL Coordinator, AIOU, Bahawalpur-Pakistan, Safdarbhatti2001@gmail.com \\ ${ }^{*}$ Corresponding Author
}

\begin{abstract}
The current paper is an expansion and comparative study of women perturbs representation via the text of two novels by two different women authors during the recent feminist movement. Angela Carter's and Margaret Atwood's novels background and text represented within its social, cultural and historical context during second wave of feminism, as it probed. It scrutinizes how this hand-picked pair of woman authors conducted feminism with woman identity in their novels and woman authors' maneuvers their skills thematic exertion strives to help contemporary world to interpret the women oppression physically and mentally under the philosophy of Simone De Bevoir. The crux of the study was that whether they remained eminent and noteworthy in portraying woman oppression in contemporary society or they were on the same bank of the river during their depiction of the sexes. The pivot of this research is through the ideology of Simone de Beauvoir, "One is not born, but rather becomes a Woman". Why and in what way women are oppressed in a patriarchal society. Both men and women should enjoy their status as human beings and must abide by their duties. Women should be judged on the basis of humanity rather than womanhood.
\end{abstract}

Keywords: woman representation, mental, physical, oppression, society, culture.

\section{INTRODUCTION AND REVIEW OF RELATED LITERATURE}

Woman persona ever remains of primary essentials among literary authors especially in centurial time where woman was appointed against cultural and civilized representations. Latter day litterateurs skillfully portray a distorted image of woman in prodigality style, traveling fringes with culture and civilization. The impairment of woman berth in literature is quite panoptical in the yesteryear's pieces of literature. Since the literary writings have been started woman ever given the status of subordinates in front of Man, and if the subordinate ever endeavors to go beyond the periphery of man's kingdom, it would be regarded as deplorable baddie. This misrepresentation had always been generated through amplification hyperbolic and excessive illustration of woman role. This fact can be justified by saying that man was the only player in the field of writing that's why he assigned woman the subordinate side of the scale. Almost it was the 19 century when woman herself decided to take part in the tract of writing some pieces of literature. Being a woman when scribbler realized its status, it decided to award the magical stick of authority in the custody of woman. Its practice has been started in every genre of literature. Dystopia is a transverse wave of utopia. The perusal of dystopia uses numerous abstractions of utopia, namely society, stability established by tyrannical governance. But dystopia peruses these concepts in a gloomy flow. Dystopia stormily summons the utopian rudimentary speculation of 
Man's consummation, declaring that humanity innate imperfections nullify the probability of contriving ideal societies excluding those that are superbly infernal. Dystopia is simply fictitious portraying forbidding repressive societies with the righteous aim of intercepting the terror they escort. Dystopia inevitably recognized the social and political affairs of latter day. That's why many of dystopias are compiled with the concern of woman oppression. It could be the outcome of second waggle in the beginning of final quarter of twentieth century when woman posture congealed in a legislative codification. In utopia woman was denied of the basic rights as to study, to choose, to vote. She is a machine to produce and to look after next generation. They were not allowed to think and speak. But it's actually man's own generated view about the existence and status of woman in society. And nature does not defined it as to subdue a woman in order to be man's symbol of conquer. In utopia or dystopia the ball of acquiescent was always thrown in the pool of woman. Woman individuality always remained the subject of harsh and authoritarian treatment under the surge of patriarchal creed. And as a consequence she herself opted the same style to rule over man to revenge the humiliation of woman in "The Passion of New Eve" and in "The Handmaid's Tale" she rejects the importance of manhood and prefers to live alone finally.

Simone de Beauvoir dismisses patriarchal oppression of woman on the biological grounds. She endows a remarkable quantum of time by writing the route pregnancy menstruation and other features of anatomy which usually defined woman be allocated as locus of oppression for woman. She started that anatomical appearance of woman oppression. Beauvoir (1949) states the enslavement of woman to the species and the restrictions of her several capabilities are exceedingly important facts. A woman body is an important element in her present position in the world. But the body could not be the only reason to define a woman's status. There is no rule living reality excluding as it is apparent in the bosom of a society by conscious individual activities. Biology is not the only grounding to portray such picture of inferiority; woman could be regarded as other. The researcher task is to find out that how the woman identity has been affected throughout the course of history. Researcher is concerned to find out what humanity has made of human woman. Simone de Beauvoir states that woman body is snarled in the anatomy of insignificance and social brutality. These are social tracings and active social stances of human awareness. A woman cannot be regarded as man's other on the biological and anatomical groundings. Beauvoir (1949) states [Humanity's] ways and customs cannot be deduced from biology, for the individuals that compose the society are never abandoned to the dictates of their nature; they are subject rather to that second nature which is custom and in which are reflected the desires and the fears that express their essential nature. It is not merely as a body, but rather as a body subject to taboos, to laws, that the subject is conscious of himself and attains fulfillment. It is with reference to certain values that he evaluates himself. And, once again, it is not upon physiology that values can be based; rather, the facts of biology take on the values that existent bestows upon them. And the manifested justifications are not logical. Patriarchy is not built on logical grounds but an ideology. Man and woman cannot be put an end. Patriarchy could not be overthrown by deracinating the whole experience of being female. After uprooting the patriarchy it would remain only an ideology. And in this recent research, researcher is going to point out the passive representation of woman in dystopian fiction.

'One is not born but rather becomes a woman' because she accepts her role silently what society has defined about her. She has given the status of "other" to man. Gender is delineated on the authority of utterly stiff regulatory outline that depicts the woman as subjugated creature in the history. Woman always remain victim of physical and mental oppression because she represents the submissive class of society as kingship of royalty lies on the part of Man. Such man's opinion about marginalization of woman is patently viewed in "The Passion of New Eve" and "The Handmaid's Tale". In the later novel man ahold of the hollow powers in state, and started to play with the muppets (woman) while controlling social, religious, canonical abstractions. And in the former novel author shows how the power leads man to treat human inhumanly. Clouds of patriarchal mindset are hovering everywhere, and darken the significance of woman presence on the planet.

In "The Passion of New Eve" the protagonist a true patriarch, a man travelled to the city of New York. Where he swindled a prostitute with his oppressive behavior and left her alone and helpless when she got pregnant, then he entered in a state in goddess Mother's territory who was a very good surgeon also and she successfully transformed the body of protagonist male into the body of female as a revenge of Lielah's insult. From that place the protagonists ran away and reached in a male dominated island ranch, and the physical oppression casted by Zero 'a true Monarch' as the protagonist did to Leilah when she was a man. New Eve forcibly married to Tristesssa a movie star a transgender male. At the time of marriage ceremony both were representing womanhood and forced to obey the order of Zero a male. Eventually Tristessa was murdered for bold step and Eve took a decision to lead a life of woman in hope that one day the convention could change. Whereas in novel "The Handmaid's Tale" woman is victimized due to possessing the fertile ovaries as they could bear children for elite class. He ruling class revised the ruling policy due to infertility in royal woman. In implementation of new rule of government several healthy and normal woman deprived of 
the blessings of normal life. Woman in Gilead state divided into categories. And handmaids are the woman chosen for bearing children. A high degree psychological and mental oppression casted upon the protagonist Offred representing the th category of handmaid.

"The Passion of New Eve" is an elusive interpretation about gender jumble which societies fabricated and entitled as commodity. Carter has thrown light on the scattered issues about woman oppression. Novel is not about rape emasculation and disaster but to highlight the patriarchal mindset and victimized of womanhood. Carter has highlighted the issues but failed to offer the solution of these problems. Uski.R (2014) is of the view that Evelyn represented the temperament of Old Adam and when surgically transformed into the new Eve, then show the positive and factual argumentativeness of modern Eve. Novel discloses the physical and mental drive of Evelyn. Carter is concerned with the credos of sleek system of thoughts about gender not only through persons but through mentality of Evelyn and Tristessa as well. Eve herself became confused after having the physique of a woman and the mindset of patriarchy. In the beginning Bursluv's sentence 'the age of reason is over' represents the mindset that reason, knowledge and mind stand for male-hood whereas body, spirit and soul were the leisure activities of women. Carter selected gender issues including man and woman mindset and problems flowing in the society. Leilah, Eve and symbol of cultural woman Tristessa all are representing the submissive and oppressive status of woman in society whereas Evelyn and Zero are the true masculine presenters. Jennifer (2016) "The Passion of New Eve" concerned with contemporary proceedings carter discusses the gender issues farther on the standardized boundaries with the effect of physical and mental oppression. The temper of the novel in description New York city as an disintegrated state show the signs of lamentation about the missing option to pick up diversities, entitled by undeniable outlying classes, disrupted systematic order of New York is a prophecy of innumerable diversification and abundance. Carter fabricated an environment on alchemical expanse depicting a human nature both of man and woman. The character of Zero whom Evelyn describes as "masculine incarnate" is a monarch of ranch a strong man but infertile. He extols the performer (actors) because he does not like Homo sapiens. He is enjoying the rank of Old Adam among his seven wives. Wives were bound to obey him because their identity was badly crushed under the casted oppression of Zero. Women were not allowed to speak and commit any crime in front of Zero. If they go for it he would punish them. Even the pigs have better status than woman on the ranch. Carter presented simultaneously a technologically and socially constructed Evelyn and Eve, appearing as a transgender robot cum man indicating towards woman's oppression by man's oppressor.

Hall (1991) the novel grew up around woman modification of Biblical account. Carter's woman is having sensational strength and innovative power. She has courage to stand in front of man's casted oppression. Zero a self-entitled "Masculinity incarnate" (TPNE: 104) gives preference to pigs than his wives, he raped new Eve abruptly, who herself comes to know in meanwhile, that how a woman feels in monarchy of man's oppression at its uttermost point. Mother and Zero both stand for patriarchy mindset. Zero proves to be the true representor of patriarchy and in reaction Mother adopts the same features to clean the world for man's existence. Novel presents the chief contrast that bed out modern concepts about woman. The diversities between organic sex and ethnically build up gender. Carter shows that woman oppression is a culturally permuted behavior. She is of the view in The Sadeian Woman "There is the unarguable fact of sexual differentiation, but separate from it, are the behavior modes of masculine and feminine, which are culturally defined variables translated in the language of common usage to the status of universals. (The Sadeian Woman: p 6). "The Passion of New Eve" (1977) portray womanhood in an accepted gender cliché that a society used to depict about woman. Novel shows whether it is organic quarrel or a societal dispute that elucidates woman in lower rank the man. All the discussion that author presents about Eve, and the role and status of man in society is a true picture of cultural mentality and the place of woman. Whereas the other novel "The Handmaid's Tale" known as woman dystopia and it induced some fear in woman that it can be the true picture of woman in the next society, again for possessing disrespectful behavior for woman. The told tale is an informal denunciation against womanhood. It summoned how woman are involved in such immoral activities that are legally banned for them. The representation of woman is a severe warning regarding conceptual and abstract aspiration of devout integrities and oppression propensity caused by woman herself.

Ehrenreieh, (1986) the outward picture of Gilead is a castle of sovereign but inside its representation is menacing and misrepresenting depiction of utopian culture and cultural woman. Here woman is free from all kind of orthodox cultures but she is the victim of subjugation just because of the revised credos by elite commanders. Healthy woman are subjugated and not allowed to speak and even think. They assigned the task only to bear children because elite woman are infertile. Elite man are also infertile as in the case of commander Fred but he is a man that's why nobody could stand and say such truth in front of him and society because it's a male dominating society. 
Amin (1987) is of the view that "The Handmaid's Tale" is a true depiction of fundamentals but practically it has lost the spirituality and humanity. The state of Gilead set down a new life system based on puritanism, expurgation, anxiety, and horror and dishonesty. Briefly speaking the customary label of actuality is imposed by authoritarian domain. Atwood used power for the prohibition of sex introduced horror just to warn society about trembling society.

CANDACEMARTIN, (2007) Atwood made up her novel to manner born deliberately in disintegrated manners. As Offred's life was smashed, she narrates the story in same fragmented style. Offred succeeded to disgruntle the reader as she herself endured life of oppression. Body is a significant in foundation of possession and power and it plays an important part evolution of identity. Ownership is a muscular word with strong insinuation. To be in possession of any other human is a terrifying prospect. In however is reality of many people's life. All through History, same oppressed Offred is presented in Novel. And Offred's relationship with Nick can be regarded as her regaining of ownership over her own body. She revisited Nick to satisfy her own physical desire, by declining the repressive custom set by the Republic of Gilead in order to take advantage of sexuality and her personhood. "One is not born a woman, but rather becomes one" said by Simon de Beauvoir (1949), the statement challenges woman representation in society as it is imparted upon her by social conventions, and this gender identity binds her to a simplified material sex. Beauvoir ascertains sex from gender. She further claims that everything helps to confirm this hierarchy she explains that tradition in society is actually responsible for male dominance and traditional family system, one of the important element that supports man's superiority over woman. . In "The Handmaid's Tale" when man gets hold of consecrated power in community, he started to control the lives of people, assign them roles, commands social, religious and ecclesiastical abstractions, appreciates to his fascination and inclination and in the case of "The Passion of New Eve" no matter it's a woman or man who will get power over other it will go to establish its own befits.

Atwood's main pivot always revolves around the social and political concerns. She contemplates the correlation betwixt man and woman as a rootstock entitlement of human rights. Her main focus is anxiety and oppression casted upon woman in society. She disputes the subjugated status of woman in society. Atwood in "The Handmaid's Tale" addresses the gender issues, divulges the terrible utilization of woman body and life as commodity and all type of women oppression in society as she depicts the distress and hardships enclosed in womanhood in her novel.

And on the other hand in "The Passion of new Eve", Evelyn is a self-centered personality, a misogynist person. In opening pages of novel Evelyn went to his flashback, remembering a lady, he went for movie, he had a date with her, and he spent night with her but was not aware of her name. It shows that woman has submissive status in his eyes. Evelyn consolidates complete features of an oppressor. After the successful biological surgery, it was very difficult for Evelyn to opt the mindset of a suppressed woman. In order to brainwash his masculinity different movies played in front of him, Tristessa, symbol of a cultured woman, a sufferer oppressed woman character is shown to him. Images of different mammal animals with their kids, unweaned children, special videos like "sea-anemones opening and closing; caves, with streams issuing from them, roses, opening to admit a bee; the sea, the moon." (TPNE, P: 72) often played in front of him in order to strengthen her mental picture as a woman. Even when she was taken to Zero's island she behaves as suppressed woman. Because she finds it much difficult to behave in a persecuted way as other woman behave in their lives. So the biological surgery failed to change the psychology of an oppressor man in to an oppressed woman.

Trisstessa, a unifying character, selected woman roles, as society manufactured woman's status as commodity. Tristessa, a will-o-the-wisp, false face of an oppressed woman, fabricated by Hollywood, out of the goggles of a patriarch. A waxwork sculpture of Tristessa also represented an image of an oppressed woman as commodity, established in a society. Through Tristessa, Carter successfully, criticizes the woman status in society. Tristessa verbalizes the true realization about woman existence in this world, as Butler (1990) remarks, "the inner truth of gender is a fabrication [-------] a true gender is a fantasy instituted and inscribed on the surface of bodies." (Gender troubles, P 51) The sufferings of Tristessa highlight the peak of idealism that what a woman should be a weeping, helpless and a body of .crushed identity.

In "The Passion of New Eve" even the modern people (man) are not ready to leave the inherited male dominated mindset just because they hold the status of being superior. And in "The Handmaid's Tale" woman are bound to obey them. In both novels Women identity has been crushed just because of having good physique she becomes a 'slut' or the wives of zero. Authors inscribe the gender issues, reveals the dreadful utilization of woman physique and commodity and all woman of society. Atwood illustrates sufferings and privation encircled in woman.Woman oppression is the fulcrum of "The Handmaid's Tale". Humiliation and anxiety in life are disclosed under the effect of Christian foundation in dystopian style.Woman identity has been crushed just because she is possessing good physical health and ovaries to bear a child. Carter 
has just tried to turn the picture of woman by giving the authority in the hands of woman, but she could not behave normally as after bearing the thousands of years of subordination under the authority of man. So in return she also opted the same rules to governs in spite of changing the environment or clearing the air she starts to finish the time(man) and considers herself space( that would never end).

Finally the protagonist (Offred) woman takes a decision to run away from the prison and takes a first step to get in the dark vehicle, nobody knows where from it comes and where to go, in order to release herself from the chains of Commander and religious fundaments. In both novels woman is marginalized by duel oppression physically and mentally. She owes to man because of culturally constructed values. Nature has not defined gender but culture imposed it. Woman is defined under the effect of imposed natural status in this world because it is man who tries to define nature according to his own interest and woman is forced to obey him as a master. Woman is trapped in the hands of man just because of her innocence and her loving nature.

\subsection{Objectives of the Study}

The core objectives of the current study were:

- To determine the woman footing in dystopia.

- To determine the significance of subordination under the influence of authoritative man.

- To determine the probability, if woman gets the status of equality in spite of subordination.

\subsection{Research Questions}

The current study answered the following questions:

- How is the woman in selected novels marginalized in the macho state?

- Why does woman accept the rank of subordination happily?

- Whether this subordination imposed on woman is by religious values or just a cultural assumption?

\section{RESEARCH METHODOLOGY}

The researchers opted qualitative research methodology that can be categorized basic perusal as it got wind strapping base to pose a question about woman depiction in dystopias by woman authors. The current study rotates around three facets:

- Original text of the novel

- Theories concerning about topics

- Criticism regarding research.

\section{FINDINGS AND CONCLUSIONS}

The current study was concerned with the subjugated treatment of woman in dystopian fiction as a result of patriarchal mindset. Simon de Beauvoir (1949) "The Second Sex" pointed out that such mindset, by stating that Man justified himself to rule over woman by putting the reason that woman is assigned the role of an inferior creature by God. She claimed that it is not defined by nature but man himself has defined it according to his own interests. Simone de Beauvoir is of the view that woman should not be defined on biological grounds. She has been forcibly arrested in the prison of insignificance and social awful brutality. It is an organized social dogging having great deal and agile social attitude of human interpretation reinforces significance for Simone de Beauvoir. A woman cannot be defined on biological grounds because "A woman is not a born but rather becomes a Woman". And the recent research is the comparative study of "The Passion of New Eve" (1977) by Angela Carter and "The Handmaid's Tale" by Margaret Atwood, concerning the same issue. In both novels the environment is clouded under the impact of patriarchy. In both novels woman is marginalized by duel oppression physically and mentally. She owes to man because of culturally constructed values. Nature has not defined gender but culture imposed it. Woman is defined under the effect of imposed natural status in this world because man himself tries to define nature according to his own interest and woman is forced to obey him as a master. Woman is trapped in the hands of man just because of her innocence and her loving nature.

\section{SUGGESTIONS AND RECOMMENDATIONS}

The researchers put forward the following suggestions and recommendations: 
- It is necessary to highlight gender issues regarding woman identity in upcoming fiction.

- It is also necessary to treat woman on equality basis.

- Laureates should play significant role in writing fiction in order to teach the inhabitants on this planet with the rules of humanity, equality and honor as defined by nature.

\section{REFERENCE LIST}

Atwood, M. (2019). The handmaid's tale. CA.

Beauvoir, S. D. (1972). The Second Sex, ed. and tr. H. M. Parshley. Harmondsworth: Penguin.

Carter, A. (1978). The Passion of New Eve (1st ed.).

Carter, A. (1979). The Sadeian Woman: An Exercise in Cultural History London: Virago.

Carter, A. (1980). The sadeian woman: And the ideology of pornogr. New York: Harper [and] Row.

Catharine, R. S. (1986, May 31). Atwood Woman. The Nation, p. 764-5.

Deer, G. (1994). "The Handmaid's Tale: Dystopia and the Paradoxes of Power. Postmodern Canadian Fiction and the Rhetoric of Authority, 93-112. Retrieved from Montreal: McGill-Queen's University Press

Dopp, J. (1994). Subject-position as Victim-position in The Handmaid's Tale. Canadian Literature 19 no 1 , 43-57..

Ehrenreich, B. (1986, March 17). "Feminism's Phantoms: The Handmaid's Tale by Margaret Atwood". The New Republic [New York], pp. 33-4, 34-5.

Foley, M. (1992). "Basic Victim Positions" and the Women in Margaret Atwood's The Handmaid's Tale. Atlantis, 15(2), 50-58. Retrieved from http://journals.msvu.ca/index.php/atlantis/article/view/4251/3495

Hall, S. (1991). INTERPRETATION, GENDER, AND THE READER: ANGELA CARTER'S SELFCONSCIOUS NOVELS. Glasgow, SC: University of Glasgow.

Malak, A. (1987). The Handmaid's Tale and the Dystopian Tradition. Canadian Literature 112 (spring), 9$11,15$.

Martin, C. (2007). Language, Identity, and Oppression: Reading Atwood's The Handmaid's Tale as Slave Narrative. Asheville: The University of North Carolina.

Uski, R. (2014). Postfeminism through magic realism in Angela Carter's The Passion of New Eve. Retrieved from k: http://urn.fi/urn:nbn:fi:uef-20140294

Weiss, A. (2009). Offred's Complicity and the Dystopian Tradition in Margaret Atwood's The Handmaid's Tale. Studies in Canadian Literature, 34(1). Retrieved from https://journals.lib.unb.ca/index.php/SCL/index

Wisker, G. (1986). 'Winged Women and Werewolves: How do we Read Angela Carter? ' in Ideas and Production. A Journal in the History of ldeas, 4, 87-98.

Wisker, G. (2012). The Oppressive Future: The Handmaid's Tale (1985). Margaret Atwood: An Introduction to Critical Views of Her Fiction, 87-98. doi:10.1007/978-0-230-35795-2_6 